Original Research Paper

\title{
Study on the Distribution of Endomycorrhizal Fungi in Some Species Root-Plants in Bali
}

\author{
Meitini Wahyuni Proborini and Deny Suhernawan Yusup \\ Department of Biology, Faculty of Natural and Basic Science, University of Udayana, Indonesia
}

\section{Article history}

Received: $13-10-2017$

Revised: 24-11-2017

Accepted: 20-12-2017

Corresponding Author:

Dr. Meitini Wahyuni Proborini

Department of Biology, Faculty of Natural and Basic Science,

University of Udayana,

Indonesia

Email: pmeitini@unud.ac.id

\begin{abstract}
Plants growing on poor soils are commonly associated with endomycorrhizal fungi as a mutualism symbiotic. The fungus takes a role on enhancement of the uptake of soil mineral nutrients particularly phosphorus, thereby enhancing host plant vigor. Despite some of Bali areas particularly in Karangasem and Buleleng have poor soil condition, less study on the endomycorrizhal fungi have been undertaken. The objective of this study are to observe the occurrence and percentage of indigenous endomycorrhizal fungi associated with plants commonly planted at Gerokgak suburb of Buleleng and Sukadana suburb of Karangasem. These two different areas in which these periods categorized as the dry and wet seasons. The root infection were observed by means of Grid-line Intersect method. The number of spores was counted by wet sieving and decanting method. The result showed all root plants species in these areas were having endomycorrhizal infection. The colonization presented as vesicle, internal-external hyphae and spore forms. The number of spore found at Sukadana was higher than those at Gerograk. Such variation could be addressed to the difference of soil texture, in which the soil texture of Gerograk was more sandy-silt and the soil texture of Sukadana was dried-sandy soil.
\end{abstract}

Keywords: Spatial, Temporal, Root Colonization, Number of Spores, Bali

\section{Introduction}

Plants growing in poor soil areas are commonly associated with endomycorrhizal fungi as a mutualism symbiotic. The Arbuscular Mycorrhizal Fungi (AMF) are abundant in almost all natural terrestrial communities and form obligate symbiotic associations with some 70$80 \%$ of vascular plants (Smith and Read, 1997). They play a vital role in sustaining plant diversity, increasing plant productivity (Delvian, 2003 and maintaining ecosystem processes by promoting plant fitness through a range of mechanisms (Brundrett et al., 2008), protecting host from soil pathogens (Smith, 2000) and improving soil structure, enhancing water and soil mineral uptake (Smith et al., 2010).

North - East Bali region is one of three regions in Bali classified as drought region and dominated by regosol soil type covered by sand resulted from volcano eruption of Agung montain (Antara, 2004). The climate is extremely dry due to less frequent rain fall (Daryana, 2010). Such environmental condition leads farming to rely on wet season (Aditya, 2011).
The plant communities in these areas are dominated by dried plant communities (Antara, 2004; Daryana, 2010). The main perennial plant developed by farmer under supervising of government is export commodity plant i.e., cashew nut (A. occidentale L.), Corn (Zea mays L) and Cassava (Manihot utilissima L.). Despite some of Bali areas particularly Karangasem and Buleleng area have poor soil condition, in which plants should be take a mutualism symbiotic with microorganisms such as endomycorrizal fungi to support these plants, less study on the endomycorrizhal fungi have been undertaken. This study is important to explore the plants associated the AMF as a symbiotic association helping the vigor of plants communities.

\section{Materials and Methods}

\section{Soil and Plant Root Sampling}

Soil and plant root sampling was spatially and temporally conducted at cashew nut plantation area in Sukadana Village Karangasem Suburb and Sendang Village Buleleng for one year from 2016 - 2017 with 
two month-interval. There root samples were taken from five plant i.e., Anacardium occidentale, Cajanus cajan, Lablab purpureus, Manihot uttilissima and Zea mays taken from Sukadana Karangasem and five plants i.e., Anacardium occidentale, L Cajanus cajan, Capsicum frutescent,s Manihot utilissima and Zea mays from Sendang Buleleng. Therefore 50 samples of root collected from both areas. The soil sampling method was adapted from Widiastuti (2004). The soil was sampled from rizhospere of all plants, soil was digging from the surrounding plant root, at $\pm 20-30 \mathrm{~cm}$ depth. The total soil sample was ten bags (@ ca.2 kg) from two areas of sampling per period.

\section{Precentage of Plant Root Colonization}

Percentage of plant root colonization was calculated by means of the method of Kormanik and Mc.Graw (1982) modified (Proborini, 1998). Plant roots sample were processed i.e., clearing, staining and destaining consecutively. The observation of VAM colonization in root cortex and endomycorrhizal hifa was carried out by means of dissecting-set and binocular microscopes.

To count the percentage of mycorrrhizal colonization by using formula is as below:

$$
\begin{aligned}
& \% \text { root length conlonization } \\
& =\frac{\sum \text { vertical cross }+ \text { horizontal cross hypha }}{\text { Total root length examined }} \times 100 \%
\end{aligned}
$$

\section{Isolation and Spore Density}

The method used for spore isolation was the wet decantation method of Brundrett et al. (2008). The endomycorrhiza was isolated from $250 \mathrm{~g}$ soil sample soaked in $1000 \mathrm{~mL}$ water (ratio of water soil is 1:4). The supernatant was decanted in five consecutive sieves (Analysensieb Eckhardt 5657 Haan W. Germany) with top down mesh size $500 \mu \mathrm{m}, 300 \mu \mathrm{m}, 200 \mu \mathrm{m}, 63 \mu \mathrm{m}$ dan $45 \mu \mathrm{m}$ consecutively. The spores found were observed under dissecting microscope and separated in accordance its morphological characters. The total number of spore was noted and the spore was fixed in a glass bottle filled containing sterilized water. The bottle was then put in refrigerator $\left(5^{\circ} \mathrm{C}\right)$.

\section{Results and Dicussion}

\section{Number Endomycorrhizal Spores}

The number of endomycorrhizal spore in the rizhosphere cashew nut plant and associated plants in the cashew nut plantation area varied spatially and temporally (Fig. 1 and 2). The total count of spores and sporocarps were 840 spores in the two different regions. The number of spores obtained directly from the field of Sukadana was 48-89 spores/100 g, meanwhile the spores taken from Sendang was $28-78$ spores/100 g. The lowest spore of Anacardium occidentale plants was found during rainy season (December 2016 - February 2017) meanwhile the highest spore numbers were found in dry season (October 2016) (Fig. 1 and 2).

According to the result showed on the Fig. 1 and 2, indicate that the highest spore number was found at the rhizosfer of cashew nut plant (A. occidentale) and the lowest was at cassava ( $M$. uttilissima) plants. Interestingly, during August and October plant of $M$. uttilissima at Sukadana and Z. mays at Sendang have been harvested as the result data of spore number was not obtained. The number of endomycorrhizal spores showed temporal variation at both locations and such variation seems related to season. This finding similar with Smith (2000; Delvian, 2006), the existence of endomycorrhiza spore in the nature is season related in which the spores number tends to decrease during rainy seasons (December, January to February). That is because the spores will germinate to hyphal shape forms and the hyphae will grow and find out water, soil mineral and host plant to elongate and furthermore they produce spores. Furthermore Delvian (2006; Chalimah et al., 2007; Brundrett et al., 2008) also demonstrated that the endomycorrhiza spore number is affected by season, soil characteristics (texture, $\mathrm{pH}$, soil mineral, age and species of host plant.

\section{Percentage of Root Colonization}

The average percentage of endomycorrhizal colonization at sample plants from both sampling area is presented at Fig. 3 and 4.

The result shows a similar trend at both sampling area, the percentage colonization decrease gradually from April up to October 2011 and increase from Oktober 2011 up to February 2012. The data of mycorrizal colonization in some plant rizhosphere was not obtained, such as cassava (M. uttilissima) by October at Sukadana-Karangasem and corn (Zea mays) by August and October and cassava (M. uttilissima) by October at Gerograk- Buleleng, these plants have been harvested. The trend of the percentage of colonization dynamic fit to rain fall data, from April up to October 2016 was dry season and October 2016 up to 2017 was rainy seasons.

The result agrees with Delvian (2006; Smith et al., 2010), hyphal colonization is season related. The colonization increase during rainy season and decrease during dry season. Such Endomycorrhyza - host plant interrelationship gives benefit to each other. Endomycorryza takes a benefit by obtaining nutrient from the host plant (Hapsoh, 2008). The host plant gets some benefits from endomycorrhiza colonization i.e., the endomycorrhiza takes a role on re-mineralization of phosphorous and providing phosphate in soil (Smith et al., 2010), on water absorbtion (Al-Zalzaleh et.al., 2009) and mineral uptake (Renuka et al., 2012) and on producing plant growth hormone-like similar to auxin, cytokine and Gyberelin (Imas et al., 1989). 


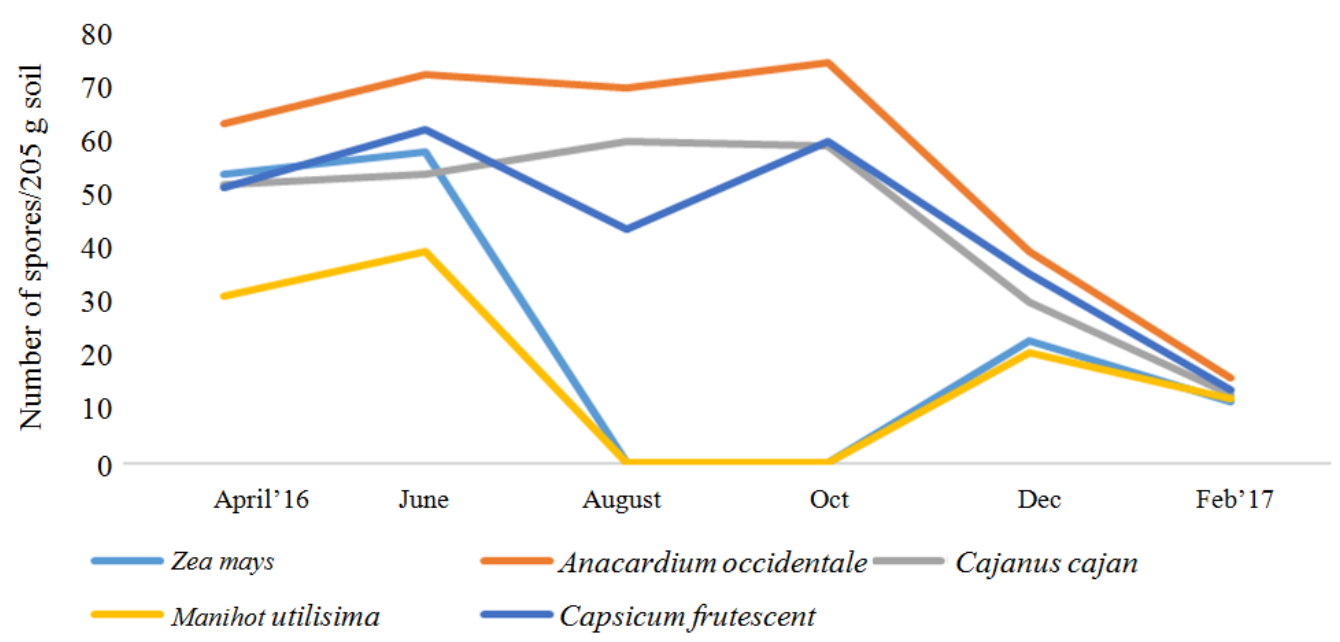

Fig. 1: Temporal variation of average spore density in associate plants rizhosphere at Sukadana Karangasem

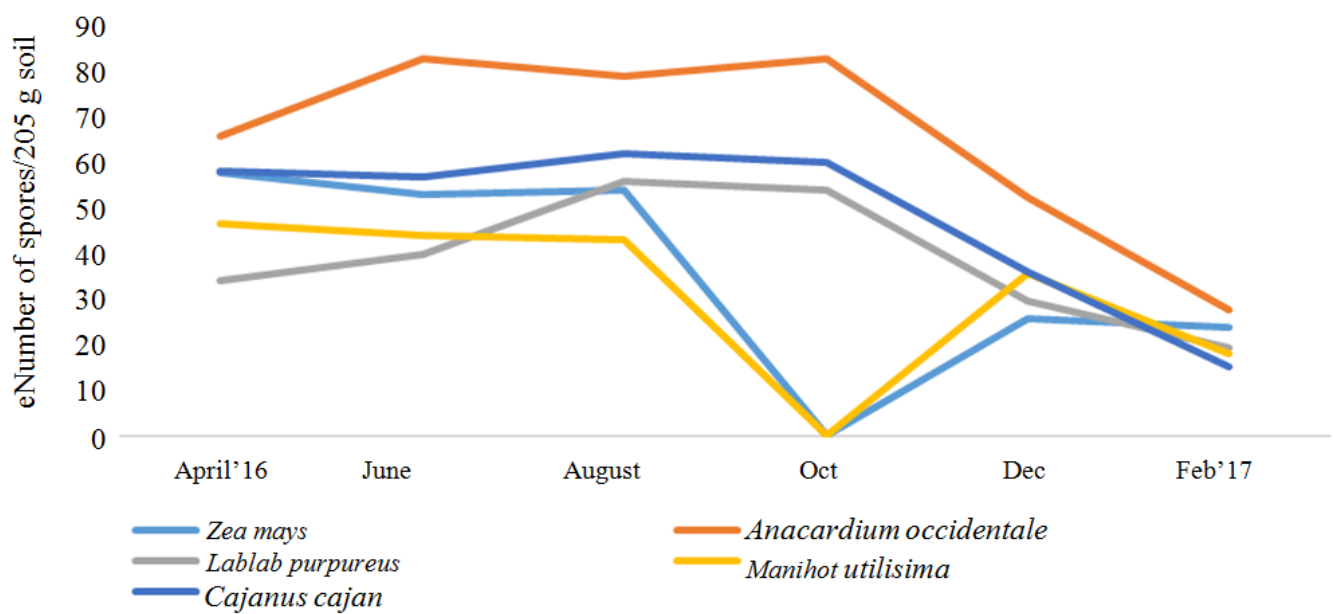

Fig. 2: temporal variation of average spore density in associate plants rizhosphere at Sendang-Buleleng

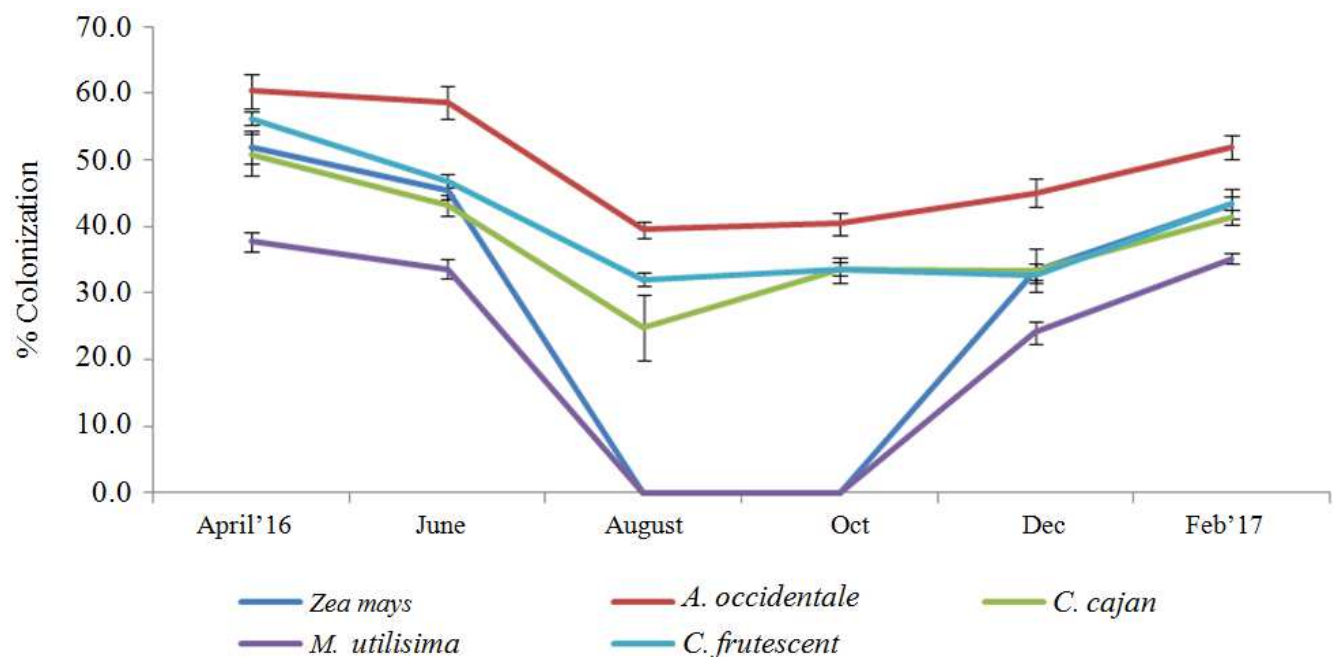

Fig. 3: Spatial and temporal variation of average percentage of endomycorrhiza coloniation in associate plants root at Cashew nut plantation at Sukadana Karangasem 


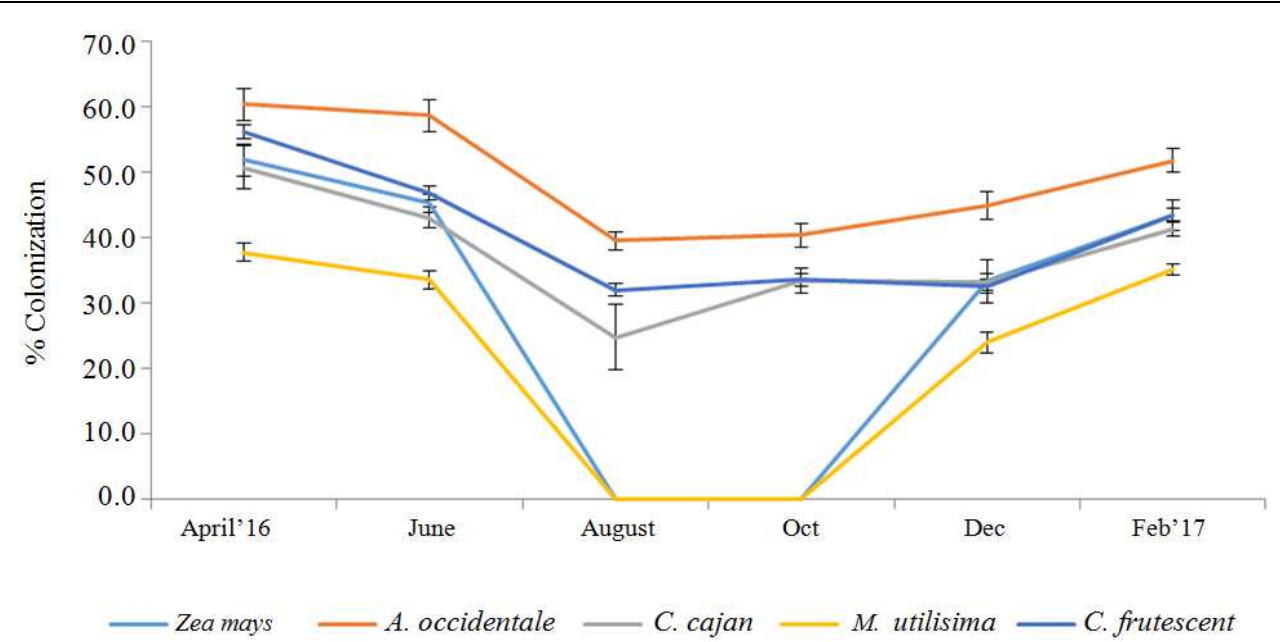

Fig. 4: Spatial and temporal variation of average percentage of endomycorrhiza coloniation in associate plants root at Cashew nut plantation at Sendang Buleleng

\section{Conclusion}

Result of the exploration can be concluded that:

1. The colonization percentage of endomycorrhizal fungi in the root of plants varies in these two arid areas

2. The spore density of endomycorrhizal fungi are varies spatially and temporally related to season

\section{Acknowledgement}

Special thanks for Harry Palmer my manuscript reviewer Thanks for Udayana University and DIKTI for Grant research of Hibah Unggulan Udayana 2017

\section{Author's Contributions}

Meitini Wahyuni Proborini: Participated in all experiments, coordinated the data-analysis and contributed to the writing of the manuscript.

Deny Suhernawan Yusup: Participated the data analysis and helping for writing the manuscript.

\section{Ethics}

This article is original and contains unpublished material. The corresponding author confirms that all of the other authors have read and approved the manuscript and there are no ethical issues involved

\section{References}

Aditya, 2011. Kondisi fisik kabupaten buleleng. Portal on line Buleleng.

Al-Zalzaleh, H.A., M.A. Majid and A.R. Mathew, 2009. VAM inoculation for selected ornamental plants in bioremediated and agricultural soils. Eur. J. Sci. Res., 25: 559-566.
Antara, M., 2004. Pendekatan agribisnis dalam pengembangan pertanian lahan kering. Makalah Seminar Pengelolaan LahanLahan Kering Beririgasi Berkelanjutan yang Berorientasi Agribisnis, Singaraja.

Bohrer, K.E. and J.P. Amon, 2004. Seasonal dynamis of arbuscular mycorrhizal fungi in differing wetland habitats. Mycorrhiza, 14: 329-337.

Brundrett, M., N. Bougher, B. Dell, T. Grove and N. Malajczuk, 2008. Working with Mycorrhizas in Forestry and Agriculture. ACIAR Monograph 32, Australian Centre for International Agricultural Research, Canberra.

Daryana, P., 2010. Padi Gogo di Kecamatan Gerogak. Dinas komunikasi dan Informasi.

Delvian, 2003. Keanekaragaman cendawan mikoriza arbuskula (CMA) di hutan pantai dan potensi pemanfaatannya (Studi kasus di hutan cagar alam Leuweung Sancang Kabupaten Garut, Jawa Barat). [disertasi]. Bogor: Program Pascasarjana, Institut Pertanian Bogor.

Delvian, 2006. Dinamika sporulasi cendawan mikoriza arbuskula. Departemen kehutanan, Fakultas Pertanian, Universitas Sumatra Utara, Medan, Indonesia.

Geeta, S.V., K. shrestha, B. Khadge, N.C. Johnson and H. Wallander, 2007. Study of biodiversity of arbuscular mycorrhizal fungi in addition with different organic matter in different seasons of kavre district (central Nepal). Sci. World, 5; 221-227.

Hapsoh, 2008. Pemanfaatan fungi mikoriza arbuskula pada budidaya kedelai di lahan kering. Makalah, Pengukuhan Guru Besar, Kampus USU, Medan, Indonesia.

Idwar dan, A.M., 2000. Pengaruh mikoriza vesikular arbusklar terhadap keefisienan penggunaan pupuk $\mathrm{p}$ oleh tanaman jagung (Zea mays L.). J. Natur Indonesia, 2: 168-178. 
Chalimah, S., Muhadiono, L. Aznam, S. Haran, N., Toruan-Mathius. 2007. Propagation of Gigaspora sp. and Acaulospora by pot culture in green house. Biodiversitas, 7: 12-19.

Imas, T., A.W. Hadioetomo, Y. Gunawan and Setiadi, 1989. Mikrobiologi tanah II. Departemen Pendidikan Dan Kebudayaan, Direktorat Jenderal Pendidikan Tinggi, PAU. ITB. 145 hal.

Kormanik, P.P. dan A.C. McGraw, 1982. Quantification of Vesicular-Arbuscular Mycorrhizae in plant roots. In N.C. Schenck (Ed). Methods and Principles of Mycorrhizal Research. The American Phytopathological Society, St. Paul.

Proborini, M.W., 1998. Spatial and temporal distribution of va mycorrhizal fungi in tasmanian heathland. Thesis, University of Tasmania, Hobart, Australia.

Renuka, G., M.S. Rao, M. Ramesh, V.P. Kumar and S.R. Reddy, 2012. Distribution and diversity of AM fungal flora in godavari belt forests andhra pradesh, India. Asian J. Exp. Biol. Sci., 3: 228-235.
Smith, F.A., 2000. Measuring the influence of mycorrhizas. New Phytol., 148: 4-6.

Smith, S.E. and D.J. Read, 1997. Mycorrhizal Symbiosis. 2nd Edn., Academic Press, London, pp; 605.

Smith, S.E., E. Facelli, S. Pope and F.A. Smith, 2010. Plant performance in stressfull environment: interpreting new and established knowledge of the roles of arbuscular mycorrizhas. Plant Soil, 326: 3-20.

Widiastuti, H., 2004. Biologi interaksi cendawan mikoriza arbuskula kelapa sawit pada tanah masam sebagai dasr pengembangan teknologi aplikasi dini. (Ringkasan Disertasi), Sekolah Pasca Sarjana, Institut Pertanian Bogor, Bogor, Indonesia. 